\title{
Lessons learnt from a large-scale curriculum reform: The strategies to enhance development work and reduce reform-related stress
}

\author{
Lotta Tikkanen $^{1}$ (D) Kirsi Pyhältö ${ }^{1,2} \cdot$ Janne Pietarinen $^{3} \cdot$ Tiina Soini $^{4}$
}

Published online: 16 November 2019

(c) The Author(s) 2019

\begin{abstract}
Sustainable school development is suggested to result in both meaningful learning and enhanced well-being for those involved in the reform work. The aim of the study was to gain a better understanding of the relations between the strategies utilised in school development work, school impact of the reform and burdening in the context of curriculum reform in Finland. Altogether 550 district-level stakeholders responsible for curriculum reform at the local level responded to the survey. Structural equation modelling (SEM) was utilised to explore the interrelations between the reform implementation strategy, collective proactive strategies of well-being, as well as reform-related stress and the perceived school impact of the reform. The results showed that the top-down-bottom-up implementation strategy was related to the school impact of the reform and to the use of collective proactive strategies and reduced levels of stress. Collective proactive strategies also contributed to lower stress levels and enhanced school impact. The results indicate that the top-downbottom-up implementation strategy provides an effective way to promote sustainable school reform in terms of enhancing the collective and cumulative learning and reducing burdening of those involved in the reform.
\end{abstract}

Keywords Curriculum reform · Reform implementation strategy · Proactive strategies $\cdot$ School development $\cdot$ Work stress

\section{Introduction}

Sustainable school development results in both meaningful learning and the advancement of pupils and teachers' well-being (Hargreaves and Fink 2006; Thoonen et al. 2012). Reforming the curriculum is suggested to be a tool that can enable such development ( $\mathrm{Ng}$ 2009; Yuen et al. 2012). Yet, curriculum reforms do

Lotta Tikkanen

lotta.tikkanen@helsinki.fi

Extended author information available on the last page of the article 
not automatically result in sustainable changes in the everyday practices of schools (Cuban 2013; Fullan and Miles 1992; Fullan 2007). In fact, school reforms are often shown to increase workload (e.g. Germeten 2011; Graczewski et al. 2007; Lainas 2010; Lasky 2005) and demand new competences (Valli and Buese 2007; Van Veen and Sleegers 2006), causing stress. This further increases teachers' and other reform stakeholders' risk for burnout (e.g. Yu et al. 2015), and reduces the chance of the reform taking root (Mendenhall et al. 2013). Reform strategy is shown to be one of the most central determinants of reform success (Pietarinen et al. 2017; Ramberg 2014). We presume that in addition to affecting reform success, the implementation strategy also significantly contributes to reform-related stress and the strategies used to manage it. However, research on the interrelation between school reform implementation strategies and the stress experienced by those responsible for it is surprisingly scarce. A few studies have focused primarily on teachers and principals involved in standard-based reforms characterised by high accountability (see Brown and Manktelow 2016; Lainas 2010; Lasky 2005; Valli and Buese 2007). Accordingly, little is known about how reform implementation strategies, in national non-standardised reforms, contribute to both meaningful learning and burdening for those carrying out the reform work. This study aims to help fill the gap in school reform literature by exploring the interrelations between the curriculum reform strategy and experienced burdening in the context of large-scale curriculum reform in Finland. More precisely, the interrelation between the reform strategy, proactive strategies of well-being, perceived impact of the curriculum reform and reformrelated stress among the educational practitioners responsible for managing the curriculum reform at the district level is explored.

\section{Curriculum reform in Finland}

The national core curriculum and local curriculums drawing on it are parts of the Finnish educational steering system. The core curriculum is reformed approximately every 10 years. The Finnish educational system, including curriculum reforms, relies on flexible accountability structures and school and teacher autonomy emphasising trust in the schools (Aho et al. 2006; Sahlberg 2015). Stakeholders from all levels of the educational system are involved in the reform. At the national level, the Council of State provides the general goals for education and the frame for time allocations for various school subjects. Finnish National Agency for Education (former: The Finnish National Board of Education) is responsible for reforming the national core curriculum based on these documents. The national core curriculum includes the general objectives and core content of teaching, and describes the mission, values and structure of the overall education (Vitikka et al. 2012). The general values of basic education defined by the national core curriculum are human rights, equality, democracy, natural diversity, preserving environmental viability and endorsing multiculturalism (The Finnish National Board of Education 2014). The core curriculum provides a general framework for basic education, rather than of a set of strict, specific and sequenced topics that must be covered. Education providers, typically the municipalities, are responsible for constructing the local curriculums based on the 
national core curriculum. Municipalities and individual schools have the freedom to decide on the educational emphasis, teaching methods and learning material. They are also allowed to determine the way in which they organise the local curriculum reform work. Some municipalities have decided to construct their own curriculums, whereas others have opted to collaborate with each other. The local curriculum work is extensive, and involves a considerable number of educational practitioners such as school administrators, principals and teachers at the district level who comprise working groups responsible for reforming the curriculum.

\section{Theoretical framework}

\section{Sustainable school development: Promoting learning and well-being}

School curriculum reforms aim at profound and long-lasting changes in schools and thus call for sustainable school development. Sustainable school development refers to context-sensitive development work, where the learning and well-being of those involved in the reform work are put on centre stage. In such school development, learning is considered both a means and the goal of the development work (see Hargreaves and Fink 2006; Thoonen et al. 2012). From this perspective, the school impact of the reform refers to the extent to which school reform helps teachers and principals to maintain the new pedagogical practices, find solutions to problems faced in everyday school life, and enhance their commitment to continuous school development (see Pietarinen et al. 2017; Sullanmaa et al. 2019). This also involves supporting rather than challenging the occupational well-being of those involved in the reform work (Soini et al. 2010; James and McCormick 2009).

In order to have a profound impact on everyday life of schools, reform stakeholders' collective learning, i.e. the translation of curriculum goals into adaptable and feasible pedagogical practices and the construction of new ways of thinking and acting (Brown and Palincsar 1989; Rauste-von Wright 2001; Resnick and Hall 1998; Stosich 2016), is crucial. This kind of meaningful, collective learning requires shared sense-making about the goals of the reform (Soini et al. 2018; Coburn 2005; Gawlik 2015; Weick et al. 2005). This entails constructing a collective understanding of the meaning of the reform, its significance, and its consequences for the school by interpreting the goals of the reform in the light of their previous knowledge, beliefs and practices (Soini et al. 2018; Coburn 2005; Evans 2007; Ketelaar et al. 2012; März and Kelchtermans 2013). Shared and coherent understanding of the reform among stakeholders at different levels of the education system is crucial for reform to take root (Pietarinen et al. 2017; Newmann et al. 2001).

Reform stakeholders' well-being plays a central role in the sustainable reform work, because it contributes to stakeholders' ability to engage in active school development work (see Soini et al. 2010; Mendenhall et al. 2013). However, due to the new challenges faced, school reforms provide a potential source of stress, meaning negative, obstructive emotions such as anger, anxiety, tension, frustration and depression (Elo et al. 2003; Friedman 2000; Kyriacou 2001) among those involved in the reform implementation. The potential sources of reform-related stress include reshaped 
objectives of teaching, demands for new knowledge and competences (Chaplain 2001; Valli and Buese 2007), increased workload (Germeten 2011; Graczewski et al. 2007; Lainas 2010; Lasky 2005; Mendenhall et al. 2013; Saunders 2013; Van Veen et al. 2005; Yuen et al. 2012), and limited resources (Spillane et al. 2002; Van Veen et al. 2005). In addition, the reforms often raise worries about pupils' learning and questions about professional competences and self-understanding (Ittner et al. 2019; Leithwood et al. 2002; März and Kelchtermans 2013; Saunders 2013; Schmidt and Datnow 2005; Spillane et al. 2002). These may turn learning into mere surviving and result in greater work stress, at least in the short term. Work stress is hazardous for occupational well-being and may also put the reform's success at risk. Extensive, prolonged work stress may lead to burnout (Freudenberger 1974). Work stress and related negative emotions may also decrease commitment to the reform efforts and increase the likelihood of engaging in dysfunctional teaching practices (Soini et al. 2010; Lasky 2005; Mendenhall et al. 2013; Saunders 2013; Van Veen et al. 2005; Wilcox and Lawson 2018). Stress is also contagious within the professional community: a crossover effect from school principals' job-induced tension to the teachers and vice versa has been reported (Westman and Etzion 1999). However, the ability of the teacher community to learn together and with students is shown to buffer stress (Pyhältö et al. 2015) and hence, it seems that thriving at work and enjoying it is also contagious. Therefore, both collective, cumulative learning within a school reform and ensuring the well-being of those responsible for it are central preconditions for sustainable reform (see James and McCormick 2009). Studies have shown that sustainable changes are difficult to achieve, because school reforms tend to have only modest effects on classroom practices, teacher and pupil learning, and increase the risk for work stress (Cuban 2013; McCormick et al. 2006). Learning and burdening are both influenced by the strategies utilised in school development.

\section{Sustainable school development strategies}

Sustainable school development strategies are used to refer to both the reform implementation strategies and the proactive strategies of well-being utilised in the reform work. Reform implementation strategy, meaning the ways in which the reform is planned and organised, are likely to influence not only learning opportunities but also to reform stakeholders' well-being (see Pyhältö et al. 2015; Ramberg 2014). Accordingly, the strategies of well-being, referring to the means to buffer stressors induced by a school reform, are an integral part of sustainable school development aiming to simultaneously promote well-being and learning (see Pietarinen et al. 2013).

\section{The top-down-bottom-up implementation strategy}

Large-scale school reforms are highly complex processes, and their success is regulated by multiple factors at different levels of the education system, ranging from the national level to the classroom level (Tikkanen et al. 2017; Fullan 2007; Leithwood et al. 2002), These factors include, for instance: the clarity of the reform goals, the extent to which the reform is aligned with the factual learning environment, and 
reform stakeholders' motivation and sense of ownership over the reform (Pietarinen et al. 2017; Pyhältö et al. 2012, 2015; Boone 2014; Ketelaar et al. 2012; Leithwood et al. 2002; Thoonen et al. 2012). The reform implementation strategy-including leadership and orchestration of reform work-plays an important role with respect to how these factors are realised, hence providing a central determinant of reform success (Fullan 2007; Petko et al. 2015). The division between top-down and bottom-up reform implementation strategies has often been made (Fullan 1994, 2007; Petko et al. 2015).

Top-down strategies, such as centralised reforms planned and led by policymakers or administrators, have been shown to have certain benefits mainly concerning the alignment between administrative-level actions, resource allocation, and the timing and dissemination of the intended development work at the district level (see Pietarinen et al. 2017; Petko et al. 2015). However, top-down reforms tend to have a weak impact on the everyday life of schools because they often fail to enhance ownership over the reform and build aligned understanding of the reform across different levels of the educational system (Chow 2013; Ng 2009). The bottom-up strategy, in which schools become decision-makers rather than implementers of administrativelevel initiatives (Honig 2004), has been suggested to promote local actors' motivation and ownership of the reform (see Boone 2014; López-Yáñez and SánchezMoreno 2013). However, the empirical evidence of the success of bottom-up strategies in large-scale reforms is not convincing (see Fullan 1994). Studies have, for instance, shown that reforms carried out merely with bottom-up approaches often fall short due to lack of administrative-level support and funding (Honig 2004; Petko et al. 2015). In addition, these reform efforts tend to fail to scale up and spread to other school communities (Kawai et al. 2014).

Due to the benefits and shortcomings of both approaches, a balanced combination of these strategies has been suggested to be effective in bringing about sustainable change (Fullan 1994, 2007; Kawai et al. 2014). The top-down-bottom-up implementation strategy integrates the initiatives from the administrative level, such as determining general goals and offering support, school leadership and teachers' active participation (Fullan 2016; Petko et al. 2015; Priestley et al. 2015; Ramberg 2014). Accordingly, the top-down-bottom-up reform implementation strategy calls for leadership for change management and the enhancement of knowledge sharing in curriculum reform - especially in local curriculum work widely involving educational practitioners and aiming to transform the national core curriculum into local curricula.

Leadership for change management refers to leadership practices that emphasise extensive stakeholder participation among, e.g. teachers, principals, policy-makers, parents, pupils and various professionals throughout the change process (Guhn 2009; Jones et al. 2013). This kind of leadership has been shown to enhance the reform's impact on the educational reality (Alkahtani 2017; Boone 2014; Guhn 2009; Hargreaves and Fink 2006; Jones et al. 2013; López-Yáñez and Sánchez-Moreno 2013; Toh 2016). Involving lots of stakeholders with different ideas of the intended change in the process (van den Akker 2003) as well as facilitating participation of those affected by the reforms requires leadership that promotes collective responsibility, mutual trust and inclusive membership as well as the creation of spaces in which 
to work together towards common goals (Adams 2013; Adams and Miskell 2016; Chow 2013; Horton and Martin 2013; Kondakci et al. 2017; Stoll et al. 2006). Such participatory leadership in change management creates opportunities for learning and reflective professional inquiry among the educational practitioners who ultimately implement the aims of the reform in the school (Leana 2011; López-Yáñez and Sánchez-Moreno 2013; Ramberg 2014; Thoonen et al. 2012). In other words, change management practices are likely to enhance knowledge sharing in school reforms.

In school reform, knowledge sharing means the utilisation of different stakeholders' competences, experiences and expertise, and extensive collaboration between the reform stakeholders (Pietarinen et al. 2017; James and McCormick 2009). Knowledge sharing has been shown to enhance curriculum coherence and fit between the reform objectives and school-level conditions (Pietarinen et al. 2017; Pyhältö et al. 2011a; Könings et al. 2007; Ng 2009; Yuen et al. 2012). Knowledge sharing can also help to build shared meanings about the reform, which can promote a sense of efficacy regarding the achievement of reform goals and a willingness to both change one's own educational practices as well as support others in development work (López-Yáñez and Sánchez-Moreno 2013). There is evidence that active knowledge sharing helps teachers to construct more holistic perceptions of how the reform will affect not just their own teaching but the school as a whole, which in turn enhances the sense of ownership of the reform (Pyhältö et al. 2012, 2014; Breiting 2008; Ketelaar et al. 2012). In other words, knowledge sharing can be used as a tool to foster shared sense-making, and thus it may help to promote collective, cumulative learning in a curriculum reform.

We propose that reform implementation strategy is a central determinant of both the school impact and the well-being created in the reform work. Empirical evidence on the kinds of curriculum reform strategies contributing to the collective and cumulative learning and well-being of those involved, is, however, scarce. We presume that in addition to benefitting the profound and long-lasting changes in school reforms, i.e. school impact, the top-down-bottom-up implementation strategy buffers burdening among those involved in such reform in three ways. Firstly, knowledge sharing can foster learning in a professional community that enables the new challenges provided by the reform to be overcome, and thus buffers negative emotions and stress (Lasky 2005; Saunders 2013; Spillane et al. 2002; Troudi and Alwan 2010). Secondly, the implementation strategy, including leadership for change management, may encourage the individuals to divide the responsibilities evenly and thus prevent the burdening of some individuals. Thirdly, the top-down-bottom-up implementation strategy, especially with knowledge sharing as a part of it, may help the individuals to learn to co-regulate their behaviours when facing stressful interactions (Pyhältö et al. 2015; James and McCormick 2009; Saunders 2013), i.e. utilise collective proactive strategies of well-being.

\section{Collective proactive strategies of well-being}

The reform stakeholders can learn and utilise different strategies to manage stress caused by reform work (Aspinwall and Taylor 1997; Greenglass et al. 1999; Kyriacou 2001; Verešová and Malá 2012). Especially active, future oriented, social and problem-focused strategies are shown to be effective in reducing work stress 
(Austin et al. 2005; Grossi 1999; Kyriacou 2001; Montgomery and Rupp 2005). This includes the acquisition of new resources that help to buffer stressful events in advance, treating possible stressors as challenges rather than threats (Gan et al. 2007; Greenglass and Fiksenbaum 2009; Schwarzer and Taubert 2002; Verešová and Malá 2012) as well as building and drawing on the collective resources at hand, i.e., utilising collective proactive strategies. Collective proactive strategies of wellbeing are generic by nature, meaning that they are not directed to a specific stressor but can be utilised in different kinds of situations (Aspinwall and Taylor 1997). These strategies play an important role in school development work, because the stressors induced by the school reforms may be unpredictable. Collective proactive strategies of well-being entail professional communities' trust in their abilities to buffer stressors by supporting each other and regulating the workload provided by a reform, i.e. co-regulative support and co-regulative competence and efficacy.

Co-regulative support refers to professional communities' ability to recognise and utilise social resources in order to regulate the workload, for instance, as perceived in large-scale school improvement efforts (see Pietarinen et al. 2013; Straud et al. 2015). It involves professional communities' abilities to support each other in not only coping with immediate stressors but also buffering potential stressors in advance (Greenglass and Fiksenbaum 2009) as well as being prepared, staying organised, and actively seeking help and support from each other (Klassen and Durksen 2014; Kyriacou 2001; Poirel et al. 2012). Social support has been shown to contribute to proactive coping and efficacy beliefs at the individual level (Greenglass and Fiksenbaum 2009; Underwood 2000). Thus, it can be assumed that mutual support enhances reform stakeholders' trust in their professional communities' competence in proactively regulating the challenges of a reform, i.e. their proactive coregulative competence and efficacy.

Co-regulative competence and efficacy refer to professional communities' capabilities and sense of collective efficacy in regulating the workload together (see Greenglass et al. 1999; Woolfolk Hoy et al. 2006). They are characterised by professional communities' trust in their abilities to overcome the challenges in their work. Such competences can, for instance, entail professional communities' capabilities in planning, searching for new information, learning new skills, and reducing work tasks that they find burdensome (see Kyriacou 2001). In school development work, proactive co-regulative competence and efficacy may entail teacher communities' trust in their skills to regulate the pace of work or set limits to work assignments.

Collective proactive strategies may play a dual role in school development: they not only contribute to well-being but also influence the success of the reform. The proactive collective strategies, especially co-regulative support, have been shown to function as a significant buffer against stressors (Pietarinen et al. 2013; Van Droogenbroeck et al. 2014), while a lack of such support from colleagues and school management has been found to engender negative attitudes towards school improvement efforts (Van Veen et al. 2005). Experienced well-being is likely to affect reform stakeholders' opportunities to engage in school development work resulting in a greater school impact. Given that professional communities' capabilities to proactively regulate the workload and collective efficacy beliefs are both associated with reduced levels of stress and burnout (Pietarinen et al. 2013; Klassen 2010), it can also be assumed that professional working 
groups' competences and efficacy in dealing with the challenges provided by reform work are related to reduced levels of reform-related stress. Proactive strategies, such as support within the professional community, are also shown to promote social learning and sustainable change (Saunders 2013; van Veelen et al. 2017). In addition, social support and possibilities to set limits to work assignments, can be seen as resources in school reforms, and as such they can promote motivation towards school development (see Bakker and Demerouti 2007) and thus contribute to school impact. Consequently, we presume that the use of collective proactive strategies within school development work may result in sustainable changes by bolstering the reform impact in terms of collective, cumulative learning, and reducing stress.

\section{Summary of the theoretical framework}

Sustainable school development refers to simultaneous enhancement of collective learning at all levels of educational system and enhancing well-being among those involved in the reform work. It can be presumed that the strategies utilised in school development, consisting of top-down-bottom-up reform implementation strategy and collective proactive strategies of well-being, are crucial in such school development. Previous studies imply, for instance, that top-down-bottom up implementation strategy, consisting of leadership for change management and knowledge sharing, can promote school impact of the reform in terms of profound, long-lasting changes (Pietarinen et al. 2017; Ramberg 2014). Moreover, knowledge sharing may further reduce burdening in curriculum reform by buffering reform-related stress and promoting the utilisation of collective proactive strategies, especially co-regulative support, within working groups responsible for constructing the local curricula (see e.g. Pyhältö et al. 2015; James and McCormick 2009; Saunders 2013; Troudi and Alwan 2010; Van Veelen et al. 2017). Co-regulative support is likely to enhance working groups' trust in their ability to regulate the workload together, i.e. sense of co-regulative competence and efficacy (see Greenglass and Fiksenbaum 2009; Underwood 2000). Collective proactive strategies utilised in school reforms may not only buffer burdening, but also enhance learning and motivation towards school development (see Bakker and Demerouti 2007; Saunders 2013; van Veelen et al. 2017), and hence contribute to the school impact of the curriculum reform. Experienced burdening, e.g. reform-related stress, in turn, is likely to negatively affect stakeholders' opportunities to engage in active school development (see Soini et al. 2010; Mendenhall et al. 2013; Van Veen et al. 2005), resulting in a decreased school impact of the curriculum reform. Empirical evidence of the interrelations between the strategies, school impact of the reform and burdening at the grass roots level in a large-scale curriculum reform is, however, deficient.

\section{Aim of the study}

The aim of the study was to contribute to school reform literature by developing a path model describing the interrelations between the components of the top-down-bottom-up reform implementation strategy crucial in local-level 
curriculum work-i.e. change management (CM) and knowledge sharing (KS) and their relations to perceived school impact of the reform (SCI), use of collective proactive strategies of well-being (i.e., perceived co-regulative support (CRS) and sense of co-regulative competence and efficacy (CRCE)) and reformrelated stress (STRESS) (see Fig. 1). The following hypothesis were tested:

H1 In the top-down-bottom-up curriculum reform strategy: change management (CM) contributes to knowledge sharing practices (KS) (Leana 2011; López-Yáñez and Sánchez-Moreno 2013; Ramberg 2014).

H2 Knowledge sharing (KS) contributes to the perceived school impact of the reform (SCI) (Pietarinen et al. 2017; Pyhältö et al. 2015; Boone 2014; Horton and Martin 2013; Petko et al. 2015; Priestley et al. 2015; Ramberg 2014), co-regulative support (CRS), including professional communities' abilities to support each other, and reform-related stress (STRESS) (Lasky 2005; Saunders 2013; Spillane et al. 2002).

H3 Collective proactive strategies of well-being contribute to both school impact of the reform and experienced reform-related stress: Perceived co-regulative support (CRS) contributes to the perceived school impact of the reform (SCI), (see Klassen and Durksen 2014; Kyriacou 2001), reform-related stress (STRESS) (see Pietarinen et al. 2013; Van Droogenbroeck et al. 2014), and a sense of co-regulative competence and efficacy (CRCE) (see Greenglass and Fiksenbaum 2009; Underwood 2000). Furthermore, a sense of co-regulative competence and efficacy (CRCE), including stakeholders' trust in their abilities to regulate workloads together, contributes to experiences of reform-related stress (STRESS) (Pietarinen et al. 2013; Klassen 2010).

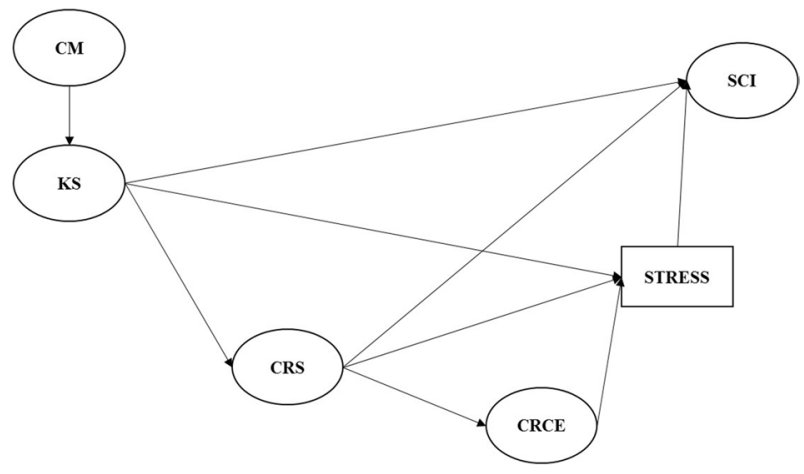

Fig. 1 Hypothesised model of the interrelations between the components of the top-down-bottom-up implementation strategy (i.e. change management (CM) and knowledge sharing (KS)), collective proactive strategies of well-being (i.e. perceived co-regulative support (CRS) and sense of co-regulative competence and efficacy (CRCE)), reform-related stress (STRESS) and the perceived school impact of the reform (SCI) 
H4 Experienced reform-related stress (STRESS) contributes to the perceived school impact of the reform (SCI) (see Soini et al. 2010; Lasky 2005; Mendenhall et al. 2013; Saunders 2013; Van Veen et al. 2005).

\section{Methods}

Previous empirical survey studies concerning large-scale school reforms are scarce. Prior research on school reforms have mostly been single or multiple case studies (see Fullan 2016) employing qualitative methodology. In addition, quantitative studies have focused on reform outcomes, such as the learning outcomes of students (see Sondergeld and Koskey 2011). Quantitative measures of reform implementation strategies are therefore largely missing. For the present study, a quantitative methodology, including the use of self-developed measures and a survey for data collection, was selected to enable conclusions to be drawn about the interrelations between the implementation strategy components (i.e. change management and knowledge sharing) and their relations with collective proactive strategies of well-being, school impact of the reform, and reform-related stress.

\section{The participants}

The collaborative networks of local curriculum making were selected for the data collection. The networks involved participants from 54 municipalities around Finland, encompassing a total of about $17 \%$ of Finnish municipalities $(n=54 / 320)$ varying in size and in terms of location (rural/urban). In practice, these curriculum making networks formed 12 case districts that were developing the local curricula. The district-level curriculum making was orchestrated into shorter-term or longer-term working groups depending on the task at hand. The working groups were formed for the curriculum reform and they can be characterised as loosely-connected. The participants $(\mathrm{N}=550)$ were members of these working groups, and represented all 12 case districts. The number of the respondents varied between the districts (Min/ Max $=15 / 93)$. The majority of the respondents were teachers $(n=403 ; 73.3 \%)$ and educational leaders, such as principals $(n=101 ; 18.4 \%)$. The participants also included other educational experts, such as municipal administrators, coordinators and student counsellors $(n=28 ; 5.1 \%)$. A few of the respondents $(n=18 ; 3.3 \%)$ did not state their occupation. The majority of the participants were females $(n=408$; $74.2 \%$ ). The mean age of the respondents was 46.0 years $(\mathrm{Min} / \mathrm{Max}=26 / 71)$. Most participants $(\mathrm{N}=335 ; 62.5 \%)$ had previous experience of a curriculum reform.

The case districts represented different ways of organising the local curriculum work, ranging from districts involving representatives from several municipalities to those carrying out the reform work within an individual municipality. Also, the number of stakeholders involved in the process and the sizes of the working groups varied between the districts. Hence, the sample represents the contexts, coalitions and means of interpreting and orchestrating large-scale educational reforms at the local level in Finland. 


\section{Measures}

The data were collected during spring 2016 by using the Curriculum Reform Inventory developed by the research group. The following scales were used: the top-down-bottom-up implementation strategy (13 items) comprising change management (3 items) and knowledge sharing (10 items) adapted from the Pietarinen et al. (2017); the collective proactive strategies of well-being (7 items) comprising co-regulative support ( 3 items) and co-regulative competence and efficacy (4 items) adapted from Pietarinen et al. (2013) and Pyhältö et al. (2011b); the school impact (6 items) adapted from the Pietarinen et. al. (2017); and reform-related stress (1 item) adapted from Elo et al. (2003). The single item stress scale was previously validated, which means that the scale has been shown to significantly differ from conceptually close measures, correlate with indicators of health and psychosocial work characteristics, e.g. perceived health and quantitative overload, in the expected directions, and have the power to discriminate between groups (Elo et al. 2003). The scales are shown in Table 2. All scales were rated on seven-point Likert scales, excluding the item reform-related stress, which was rated on a ten-point scale. The reliability of the scales was assessed using Cronbach alpha coefficients (see Table 1). The alphas were sufficient, ranging from .79 to .91 (Nunnally and Bernstein 1994). The constructs and items used in the study are shown in "Appendix 1" section.

\section{Analysis}

In the first phase of the analysis, the factorial structure of each sub-scale (i.e. change management, knowledge sharing, co-regulative support, co-regulative competence and efficacy, and school impact of the reform) was tested separately using confirmatory factor analysis (CFA), i.e. analysing the adequate construct

Table 1 Descriptive statistics of the scales

\begin{tabular}{lllllll}
\hline Variable & 1. & 2. & 3. & 4. & 5. & 6. \\
\hline 1. Knowledge sharing & - & & & & & \\
2. Change management & .71 & - & & & & \\
3. Co-regulative support & .52 & .34 & - & & & \\
4. Co-regulative compe- & .38 & .33 & .59 & - & & \\
$\quad$ tence and efficacy & & & & & & \\
5. School impact & .59 & .45 & .47 & .35 & - & \\
6. Reform-related stress & -.23 & -.20 & -.21 & -.34 & -.16 & - \\
$M$ & 4.60 & 4.10 & 4.81 & 4.40 & 4.76 & 5.36 \\
SD & 1.11 & 1.43 & 1.00 & 1.03 & .96 & 2.55 \\
Min & 1 & 1 & 1 & 1 & 1.33 & 1 \\
Max & 7 & 7 & 7 & 7 & 7 & 10 \\
$\alpha$ & .91 & .82 & .79 & .80 & .87 & - \\
\hline
\end{tabular}

Reform-related stress was rated on a ten-point scale, whereas others were rated on seven-point scales

All correlations were statistically significant at $p<.001$ level 
validity of each measurement model. The analyses were carried out using an MPlus statistical package (version 7.4). The parameters of the measurement models were estimated using a robust maximum likelihood (MLR) procedure, because it produces maximum likelihood estimates with standard errors and $\chi^{2}$ test statistics that are robust to non-normality (Muthén and Muthén 2012). The goodness-of-fit of the estimated standardised model was assessed using a $\chi^{2}$ test, Comparative fit index (CFI), Tucker-Lewin Index (TLI), Root Mean Square Error of Approximation (RMSEA), and Standardised Root Mean Square Error of Approximation (SRMR) (Muthén and Muthén 2012). The construct validity analysis showed that, on the basis of the several goodness-of-fit indices (see "Appendix 2" section), the correlations between items and latent factor fitted the expected patterns in each sub-scale (e.g. Bentler and Bonett 1980; Bollen 1989; $\mathrm{Hu}$ and Bentler 1999) and hence contributed to the previously gathered evidence of the measurements' construct validity (Sullanmaa et al. 2019). Theoretically solid correlations between some of the residuals were added to the measurement models (see Fig. 2) when they significantly improved the model and were substantively meaningful (Byrne 2012). The rationale behind adding the correlations between the residuals of the items $\mathrm{KS} 1, \mathrm{KS} 2$, and $\mathrm{KS} 4$ was that all these items reflected individuals' opportunities to contribute to the reform, i.e. agency in terms of curriculum making, and for items KS3 and KS12 that both of them measured the reform stakeholders' collaborative efforts in constructing the reform process. Also the correlations between the residuals of the items SCI06 and SCI10 were added, because both of them reflected the perceived impact of

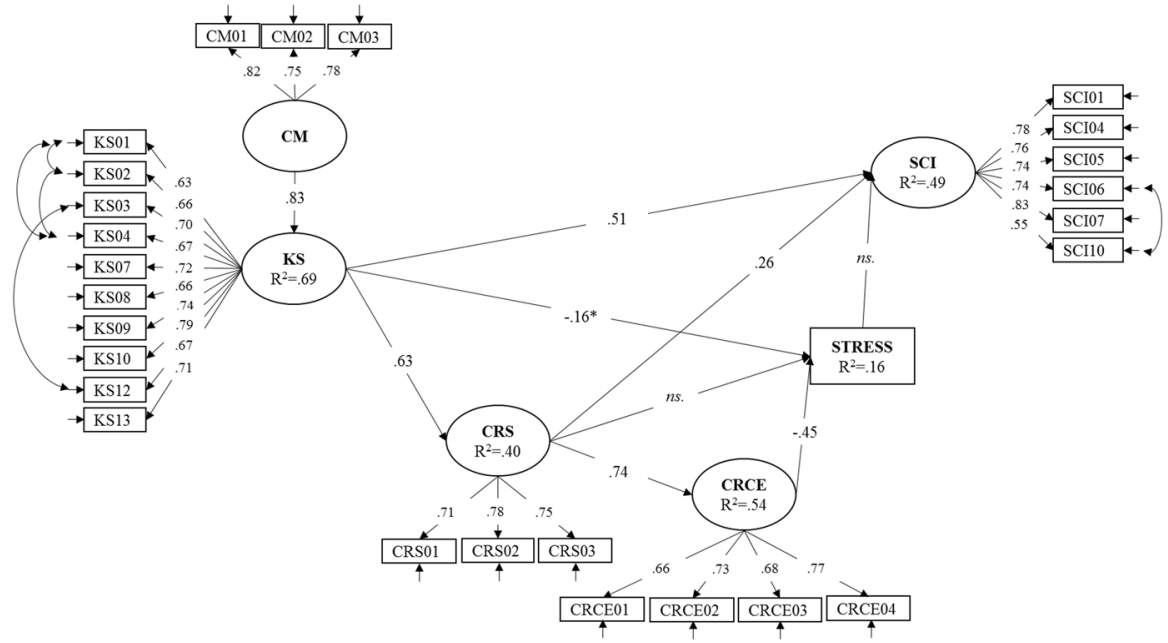

Fig. 2 The interrelations between top-down-bottom-up implementation strategy (i.e. change management (CM) and knowledge sharing (KS)), collective proactive strategies of well-being (i.e. co-regulative support (CRS) and co-regulative competence and efficacy (CRCE)), reform-related stress (STRESS) and the school impact of the reform (SCI). Standardised model: $\left(\chi^{2}(311, \mathrm{~N}=548)=665.03, p<.001\right.$; RMSEA $=.046(90 \%$ C.I. $=.041-.050)$; CFI/TLI $=.94 / .93$; SRMR $\left.=.045) .{ }^{*}\right) p<.01$. All other parameters were significant at $p$ level $<.001$ 
the reform particularly in terms of solving problems. Factor determinacies of the scales are shown in "Appendix 1" section.

In the second phase, the hypothesised model (Fig. 1) was further tested using structural equation modelling (SEM), which enabled determination of the extent to which the hypothesised path model was consistent with the data (Muthén and Muthén 2012). The goodness-of-fit of the estimated standardised model was similarly assessed using a $\chi^{2}$ test, Comparative fit index (CFI), Tucker-Lewin Index (TLI), Root Mean Square Error of Approximation (RMSEA), and Standardised Root Mean Square Error of Approximation (SRMR) (Muthén and Muthén 2012).

\section{Results}

\section{Local curriculum work perceived by educational stakeholders}

The results showed that the participants on average perceived that the reform was implemented by employing the top-down-bottom-up implementation strategy both in terms of knowledge sharing and change management. Accordingly, they reported being able to contribute to the reform work and that the perspectives and competences of multiple stakeholders were utilised. They also reported successful leadership practices and division of work. The reform stakeholders also estimated the reform impact to be high, implying that reform work helped to solve problems faced in everyday school life and enhanced stakeholders' engagement in continuous school development at the district level. In addition, they reported using collective proactive strategies of well-being both in terms of perceived co-regulative support and sense of co-regulative competence and efficacy. Accordingly, the results indicated participants' trust in their abilities to buffer the potential stressors in advance by regulating their workload together and supporting each other. The stakeholders reported moderate levels of reformrelated stress. All means and correlations are shown in Table 1.

The investigation of the correlations showed that the elements of topdown-bottom-up reform implementation strategy, i.e. change management and knowledge sharing, were positively related to each other. Knowledge sharing was positively related to perceived school impact, co-regulative support, and negatively to reform-related stress. Co-regulative support was related to increased levels of perceived school impact as well as a sense of co-regulative competence and efficacy. The use of collective proactive strategies, i.e. co-regulative support and co-regulative competence and efficacy, were also negatively related to reform-related stress. The collective proactive strategies were also related to higher levels of perceived school impact. Reform-related stress was negatively related to school impact. All correlations between the factors were statistically significant and ranged from weak to moderate $\left(r^{\min / \max }=-.16 / .71\right)$, suggesting interrelations between the factors in the expected directions. 


\section{The path model of reform implementation strategy, collective proactive strategies, school impact, and reform-related stress}

The results of structural equation modelling are shown in Fig. 2. Several fit indices implied that the hypothesised model fitted the data: $(\chi 2(311, \mathrm{~N}=548)=665.03$, $p<.001 ; \mathrm{RMSEA}=.046(90 \%$ C.I. $=.041-.050)$; CFI/TLI $=.94 / .93 ; \mathrm{SRMR}=.045)$.

Firstly, the results supported hypothesis one (H1), suggesting that successful change management contributed to knowledge sharing (.83). This means that in the top-down-bottom-up reform implementation strategy change management, such as clear division of work and efficient dissemination of information promoted knowledge sharing practices, for instance, the utilisation of the perspectives and competences of several stakeholders.

Secondly, knowledge sharing further contributed to the perceived school impact of the reform (.51), suggesting that the reform stakeholders' perceptions of their opportunities to contribute to reform work had an influence on their views of the extent to which reform succeeded in promoting school development at the district level. Knowledge sharing was also related to perceived co-regulative support (.63) and reformrelated stress $(-.16)$, meaning that the opportunities to contribute to school reform as well as utilisation of different perspectives and competences enhanced reform stakeholders' mutual support within working groups, and also significantly buffered their experiences of reform-related stress. Accordingly, hypothesis two was confirmed (H2).

Thirdly, it was hypothesised (H3) that collective proactive strategies of well-being contribute to the perceived school impact of the reform and reform-related stress. This hypothesis was also partially supported by the results: Co-regulative support seemed to contribute to the perceived school impact (.26). This implied that participants' trust in mutual support within working groups enhanced perception of the reform as having profound, long-lasting school impact, for instance, helping the stakeholders to engage in continuous school development. Perceived co-regulative support further contributed to stakeholders' sense of co-regulative competence and efficacy (.74), indicating that the stakeholders' mutual support within the professional community promoted their sense of capability and efficacy in regulating the workload together. The sense of co-regulative competence and efficacy, in turn, contributed to reform-related stress $(-.45)$, suggesting that the participants' trust in their capabilities to limit the development work and regulate the pace of work, buffered burdening in the context of school reform. However, co-regulative support did not have a direct impact on experienced reform-related stress.

Finally, reform-related stress was hypothesised to contribute to the perceived school impact of the reform (H4). This hypothesis was not supported by the results, indicating that the level of experienced reform-related stress did not have direct impact on the participants' perceptions of the extent to which reform succeeded in promoting school development at the district level.

Overall, the results showed that knowledge sharing together with perceived coregulative support significantly explained the perceived school impact $\left(\mathrm{R}^{2}=.49\right)$. In addition, knowledge sharing, and a sense of co-regulative competence and efficacy, significantly explained reform-related stress $\left(\mathrm{R}^{2}=.16\right)$, reflecting that the strategies utilised in school reform played crucial roles regarding well-being and collective, cumulative learning. 


\section{Discussion}

This study sheds light on the anatomy of sustainable school reform characterised by the simultaneous promotion of collective and cumulative learning and well-being by providing insights into (1) the internal dynamics of the top-down-bottom-up reform implementation strategy, (2) the functions of the reform implementation strategy and proactive strategies of well-being utilised in school development, and (3) the interrelations between learning and burdening in a school reform context.

Firstly, the results showed that in the top-down-bottom-up reform strategy leadership for change management (e.g. clear division of work and active informing of all educational stakeholders about ongoing curriculum work) enhanced stakeholders' opportunities to engage in knowledge sharing practices (Chow 2013; Gu and Johansson 2013; Stoll et al. 2006) (H1). This indicates that such leadership practices are central to promoting local educational stakeholders' participation in a reform and, thus, ownership of it (Pyhältö et al. 2015; Horton and Martin 2013; Ketelaar et al. 2012). This result implies that the top-down-bottom-up reform implementation strategy (see e.g. Pietarinen et al. 2017; Ramberg 2014) can be explored in terms of leadership for change management and knowledge sharing, and also that as a top-down approach participative leadership practices, seem to support the bottomup initiatives, such as district level stakeholders' collaborative efforts to construct the reform process and build an interactive atmosphere.

Secondly, the strategies utilised in the curriculum reform work, i.e. reform implementation strategy and proactive strategies of well-being, seemed to play crucial roles regarding collective learning in school development. The results suggested that the top-down-bottom-up reform implementation strategy had an important function as a facilitator of collective, cumulative learning. More specifically, knowledge sharing in working groups, i.e. utilisation of different perspectives, interactive atmosphere, and opportunities to contribute to curriculum reform, enhanced the perceived school impact of the reform (H2), as was expected on the basis of previous findings (Pietarinen et al. 2017; Pyhältö et al. 2015; Boone 2014; Petko et al. 2015; Priestley et al. 2015; Ramberg 2014). This result further suggests that knowledge sharing can be used as a strategic tool to enable shared sense-making within the district level and, hence, it can contribute to collective, cumulative learning. In addition, the educational professionals' capacity to support each other during the reform work (i.e. coregulative support) promoted the perceived school impact in terms of solving problems and maintaining the continuous development work in everyday school life (H3).

Thirdly, the strategies also performed significant functions in buffering burdening in school development work. Knowledge sharing promoted perceived co-regulative support within the working groups and reduced stakeholders' reform-related stress (H2). This novel result suggests that a curriculum renewal process involving multiple stakeholders, utilising their competences and taking into account different views, as well as promoting interactive atmosphere, seemed to buffer burdening both directly and through learning of collective proactive strategies. Accordingly, collective proactive strategies seemed to play an important role regarding the well-being of those involved in the reform work. Co-regulative support did not directly contribute 
to reform-related stress, as was expected based on previous studies (see Pietarinen et al. 2013; Van Droogenbroeck et al. 2014), but rather seemed to have an impact on experienced reform-related stress through the sense of co-regulative competence and efficacy (H3). More specifically, educational practitioners' trust in their capabilities to limit the workload (i.e. co-regulative support) enhanced their sense of competence and efficacy in coping with challenges triggered by the reform work (i.e. co-regulative competence and efficacy) (see also Pietarinen et al. 2013; Klassen 2010), which further seemed to buffer the experiences of reform-related stress. In other words, utilising collective proactive strategies that strengthened the use of social resources in working groups promoted effective curriculum reform work at the district level and enhanced educational stakeholders' capacity to deal with stressors. Given that the working groups were short-term and loosely-connected, and the members did not necessarily know each other beforehand, they had to have learnt these collective strategies during the curriculum reform work. This suggests that learning is also crucial with regard to well-being, because reform stakeholders can learn new strategies to buffer burdening in the context of school reform, even though the primary focus was on facilitating shared school improvement efforts.

Accordingly, this study contributes to the literature on school reforms by showing that learning and well-being are intertwined in a complex way in the implementation of large-scale school reforms (see also Pyhältö et al.2015; Soini et al. 2010). The experienced burdening did not directly contribute to collective, cumulative learning in terms of the perceived school impact of the reform, as was expected (see Soini et al. 2010; Lasky 2005; Mendenhall et al. 2013; Saunders 2013; Van Veen et al. 2005) (H4), but rather the strategies utilised in school development seemed to play central roles in regulating the interaction between burdening and collective, cumulative learning. The function of the top-down-bottom-up reform implementation strategy, especially with knowledge sharing as a part of it, seemed to be twofold in the district level reform work: the results implied that the top-down-bottom-up reform implementation strategy contributes directly to the school impact in terms of maintaining the development work and reduces burdening directly and through the learning of collective proactive strategies. The collective proactive strategies of well-being also performed multiple functions in school reform as they seemed to facilitate learning and buffer reform-related stress.

In the light of the results, the curriculum reform work seemed rather promising at the district level. Although further investigation is needed to draw conclusions concerning the anatomy of sustainable school development at the school level, the top-down-bottom-up implementation strategy is likely to be functional at school level as well, because of its benefits concerning the school impact of the reform and well-being. Utilising the top-down-bottom-up implementation strategy at the school level may also buffer the occurrence of differences between the schools in school impact of the reform and burdening. Based on the results of the study the following implications for future school reforms can be provided:

- As learning and well-being are intertwined in school development, the school leaders should take the simultaneous promotion of learning and well-being as a primary goal of a school reform. 
- It is beneficial to put efforts into developing functional leadership practices such as building a clear division of work and briefing the stakeholders frequently during the reform.

- Knowledge sharing should be intentionally promoted by making sure that multiple stakeholders' perspectives are taken into account and they have opportunities to contribute to reform work. Also, building a culture of trust and interaction is beneficial in terms of learning and well-being.

- The opportunities for reform stakeholders to learn collective proactive strategies, such as supporting each other and regulating the workload and the pace of development work together, should be intentionally created in school reforms.

\section{Limitations}

Different types of fit indices can be used to evaluate the model fit (Bentler 2007; Miles and Shevlin 2007). In this study, several fit indices (RMSEA, CFI, TLI, SRMR) indicated that the model fit the data. However, according to the Chi square test, the model fit was not acceptable. This is likely to have resulted from a relatively large sample size (Iacobucci 2010; Miles and Shevlin 2007).

The sample adequately represented different types of municipalities in Finland and the variations of carrying out the local curriculum processes at the district level, which implies that the results can be generalised nationally. However, due to the distinctive nature of Finnish educational system (see Sahlberg 2015), further studies are needed to confirm the findings across the different types of educational systems. More specifically, the scales have thus far not been validated in other school systems or large-scale curriculum reforms abroad. Further construct validation of the scales introduced in this study is therefore needed. As the working groups were formed for the curriculum reform, they were shortterm and loosely associated communities compared to, for instance, established teacher communities. The results should be interpreted in the light of this notion.

This study was conducted with cross-sectional design, which means that conclusions about the casual relationships cannot be drawn. Future longitudinal studies are, therefore, of importance to explore causal relations between the variables. In addition, using single-item stress scale enables the conclusions to be drawn only concerning the level of reform-related stress. In future it may also be fruitful to explore different types of stress to gain more detailed insight into the development of burdening in school reforms.

Acknowledgements Open access funding provided by University of Helsinki. Funding was provided by the Ministry of Education and Culture (Grant No. 6600567) and the Academy of Finland (Grant No. 295022).

Open Access This article is distributed under the terms of the Creative Commons Attribution 4.0 International License (http://creativecommons.org/licenses/by/4.0/), which permits unrestricted use, distribution, and reproduction in any medium, provided you give appropriate credit to the original author(s) and the source, provide a link to the Creative Commons license, and indicate if changes were made. 


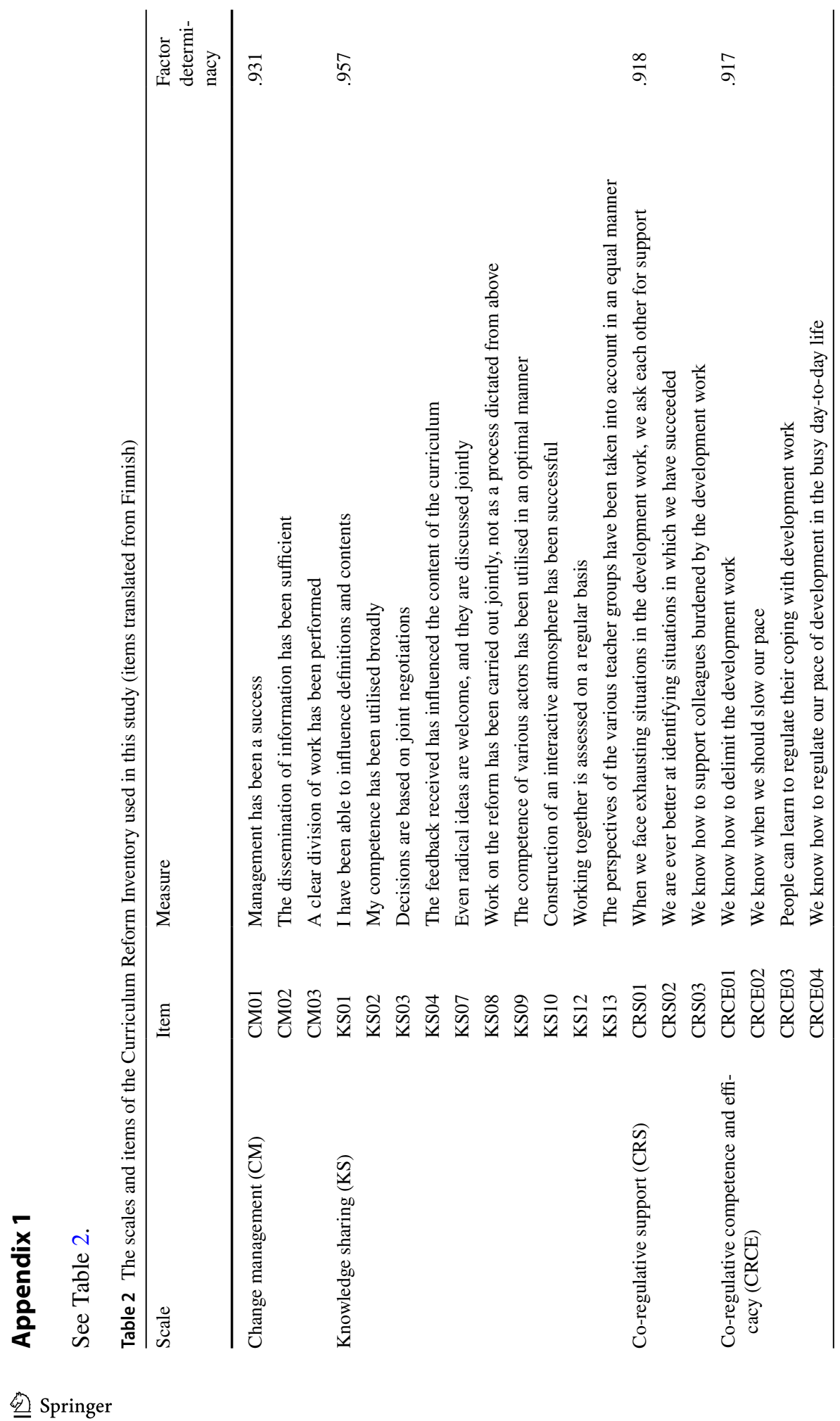




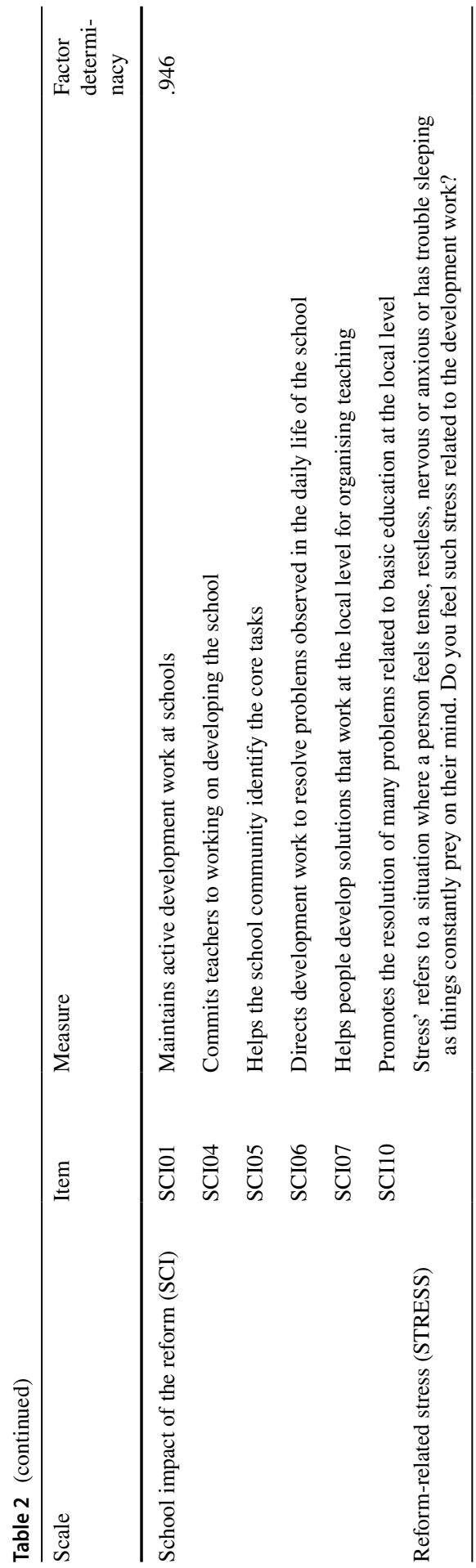




\section{Appendix 2}

\section{See Table 3.}

Table 3 Measurement models and their fit indices

\begin{tabular}{|c|c|}
\hline Measurement model & Fit indices \\
\hline $\begin{array}{l}\text { The top-down-bottom-up reform implementation strategy (i.e. } \\
\text { change management (CM), knowledge sharing (KS)), two- } \\
\text { factor model }\end{array}$ & $\begin{array}{l}\chi 2(60, \mathrm{~N}=545)=192.57 p<.001 \\
\mathrm{RMSEA}=.064(90 \% \text { C.I. }=.054-.074) \\
\mathrm{CFI} / \mathrm{TLI}=.95 / .94 \\
\mathrm{SRMR}=.039\end{array}$ \\
\hline $\begin{array}{l}\text { The collective proactive strategies of well-being (i.e. co-regu- } \\
\text { lative support (CRS), co-regulative competence and efficacy } \\
\text { (CRCE)), two-factor model }\end{array}$ & $\begin{array}{l}\chi 2(13, \mathrm{~N}=542)=49.65 p<.001 \\
\mathrm{RMSEA}=.072(90 \% \text { C.I. }=.052-.094) \\
\mathrm{CFI} / \mathrm{TLI}=.96 / .93 ; \\
\mathrm{SRMR}=.037\end{array}$ \\
\hline The school impact of the reform (SCI) & $\begin{array}{l}\chi^{2}(8, \mathrm{~N}=547)=14.14, p>.05 \\
\mathrm{RMSEA}=.037(90 \% \text { C.I. }=.000-.069) \\
\text { CFI/TLI }=.99 / .99 \\
\text { SRMR }=.019\end{array}$ \\
\hline
\end{tabular}

\section{References}

Adams, C. M. (2013). Collective trust: A social indicator of instructional capacity. Journal of Educational Administration, 51(3), 363-382. https://doi.org/10.1108/09578231311311519.

Adams, C. M., \& Miskell, R. C. (2016). Teacher trust in district administration. A promising line of inquiry. Educational Administration Quarterly, 52(4), 675-706. https://doi.org/10.1177/00131 $61 X 16652202$.

Aho, E., Pitkänen, K., \& Sahlberg, P. (2006). Policy development and reform principles of basic and secondary education in Finland since 1968. Washington: The World Bank.

Alkahtani, A. (2017). Curriculum change management and workload. Improving Schools, 20(3), 209221. https://doi.org/10.1177/1365480217706789.

Aspinwall, L. G., \& Taylor, S. E. (1997). A stitch in time. Psychological Bulletin, 121(3), 417-436. https ://doi.org/10.1037/0033-2909.121.3.417.

Austin, V., Shah, S., \& Muncer, S. (2005). Teacher stress and coping strategies used to reduce stress. Occupational Therapy International, 12(2), 63-80. https://doi.org/10.1002/oti.16.

Bakker, A. B., \& Demerouti, E. (2007). The job demands-resources model: State of the art. Journal of Managerial Psychology, 22(3), 309-329. https://doi.org/10.1108/02683940710733115.

Bentler, P. M. (2007). On tests and indices for evaluating structural models. Personality and Individual Differences, 42(5), 825-829. https://doi.org/10.1016/j.paid.2006.09.024.

Bentler, P. M., \& Bonett, D. G. (1980). Significance tests and goodness-of-fit in the analysis of covariance structures. Psychological Bulletin, 88, 588-606. https://doi.org/10.1037/0033-2909.88.3.588.

Bollen, K. A. (1989). Structural equation with latent variables. New York: Wiley.

Boone, S. (2014). Using organizational learning to increase operational and conceptual mental models within professional learning communities. Journal of Psychological Issues in Organizational Culture, 5(3), 85-99. https://doi.org/10.1002/jpoc.21152.

Breiting, S. (2008). Mental ownership and participation for innovation in environmental education and education for sustainable development. In S. L. A. Reid, P. B. B. Jensen, J. Nikel, \& A. P. V. Simovska (Eds.), Participation and learning (pp. 159-180). Amsterdam: Springer. 
Brown, Z., \& Manktelow, K. (2016). Perspectives on the standards agenda: Exploring the agenda's impact on primary teachers' professional identities. Education, 44(1), 68. https://doi.org/10.1080/03004 279.2015.1089920.

Brown, A. L., \& Palincsar, A. S. (1989). Guided, cooperative learning and individual knowledge acquisition. In L. B. Resnick (Ed.), Knowing, learning, and instruction: Essays in honor of Robert Glaser (pp. 393-451). Hillsdale: Lawrence Erlbaum Associates Inc.

Byrne, B. M. (2012). Structural equation modeling with MPlus: Basic concepts, applications, and programming. London: Routledge Academic.

Chaplain, R. P. (2001). Stress and job satisfaction among primary headteachers: A question of balance? Educational Management \& Administration, 29(2), 197-215. https://doi.org/10.1177/0263211X01 0292005.

Chow, A. (2013). Managing educational change: A case of two leadership approaches. International Journal of Leadership in Education, 16(1), 34-54. https://doi.org/10.1080/13603124.2012.672654.

Coburn, C. E. (2005). Shaping teacher sensemaking: School leaders and the enactment of reading policy. Educational Policy, 19(3), 476-509. https://doi.org/10.1177/0895904805276143.

Cuban, L. (2013). Why so many structural changes in schools and so little reform in teaching practice? Journal of Educational Administration, 51(2), 109-125. https://doi.org/10.1108/095782313113046 61.

Elo, A., Leppänen, A., \& Jahkola, A. (2003). Validity of a single-item measure of stress symptoms. Scandinavian Journal of Work, Environment \& Health, 29(6), 444-451. https://doi.org/10.5271/sjweh .752 .

Evans, A. E. (2007). School leaders and their sensemaking about race and demographic change. Educational Administration Quarterly, 43(2), 159-188. https://doi.org/10.1177/0013161X06294575.

Freudenberger, H. J. (1974). Staff burn-out. Journal of Social Issues, 30(1), 159-165. https://doi. org/10.1111/j.1540-4560.1974.tb00706.x.

Friedman, I. A. (2000). Burnout in teachers: Shattered dreams of impeccable professional performance. Journal of Clinical Psychology, 56(5), 595-606. https://doi.org/10.1002/(SICI)1097-4679(20000 5)56:5\%3c595:AID-JCLP2\%3e3.0.CO;2-Q.

Fullan, M. (1994). Coordinating top-down and bottom-up strategies for educational reform. In R. J. Anson (Ed.), Systemic reform: Perspectives on personalizing education (pp. 7-23). Washington, DC: Office of Educational Research and Improvement (ED).

Fullan, M. (2007). The new meaning of educational change (4th ed.). New York: Teachers College Press.

Fullan, M. (2016). The elusive nature of whole system improvement in education. Journal of Educational Change, 17(4), 539-544. https://doi.org/10.1007/s10833-016-9289-1.

Fullan, M., \& Miles, M. B. (1992). Getting reform right: What works and what doesn't. Phi Delta Kappan, 73(10), 744-752.

Gan, Y., Yang, M., Zhou, Y., \& Zhang, Y. (2007). The two-factor structure of future-oriented coping and its mediating role in student engagement. Personality and Individual Differences, 43(4), 851-863. https://doi.org/10.1016/j.paid.2007.02.009.

Gawlik, M. A. (2015). Shared sense-making: How charter school leaders ascribe meaning to accountability. Journal of Educational Administration, 53(3), 393-415. https://doi.org/10.1108/ JEA-08-2013-0092.

Germeten, S. (2011). The new national curriculum in Norway: A change in the role of the principals? Australian Journal of Education, 55(1), 14-23. https://doi.org/10.1177/000494411105500103.

Graczewski, C., Ruffin, M., Shambaugh, L., \& Therriault, S. B. (2007). Selecting and implementing whole school improvement models: A district and school administrator perspective. Journal of Education for Students Placed at Risk, 12(1), 75-90. https://doi.org/10.1080/10824660701247283.

Greenglass, E., \& Fiksenbaum, L. (2009). Proactive coping, positive affect, and well-being: Testing for mediation using path analysis. European Psychologist, 14(1), 29-39. https://doi. org/10.1027/1016-9040.14.1.29.

Greenglass, E., Schwarzer, R., Jakubiec, D., Fiksenbaum, L., \& Taubert, S. (1999). The proactive coping inventory (PCI): A multidimensional research instrument. http://estherg.info.yorku.ca/files /2014/09/pci.pdf. Retrieved April 27, 2017.

Grossi, G. (1999). Coping and emotional distress in a sample of Swedish unemployed. Scandinavian Journal of Psychology, 40(3), 157-165. https://doi.org/10.1111/1467-9450.00113.

Gu, Q., \& Johansson, O. (2013). Sustaining school performance: school contexts matter. International Journal of Leadership in Education, 16(3), 301-326. https://doi.org/10.1080/13603 124.2012.732242. 
Guhn, M. (2009). Insights from successful and unsuccessful implementations of school reform programs. Journal of Educational Change, 10(4), 337-363. https://doi.org/10.1007/s10833-008-9063-0.

Hargreaves, A., \& Fink, D. (2006). Sustainable leadership. San Francisco: Jossey-Bass.

Honig, M. I. (2004). Where's the "up" in bottom-up reform? Educational Policy, 18(4), 527-561. https:// doi.org/10.1177/0895904804266640.

Horton, J., \& Martin, B. N. (2013). The role of the district administration within professional learning communities. International Journal of Leadership in Education, 16(1), 55-70. https://doi. org/10.1080/13603124.2012.671366.

Hu, L., \& Bentler, P. M. (1999). Cutoff criteria for fit indexes in covariance structure analysis: Conventional criteria versus new alternatives. Structural Equation Modeling, 6, 1-55. https://doi. org/10.1080/10705519909540118.

Iacobucci, D. (2010). Structural equations modeling: Fit indices, sample size, and advanced topics. Journal of Consumer Psychology, 20(1), 90-98. https://doi.org/10.1016/j.jcps.2009.09.003.

Ittner, D., Hagenauer, G., \& Hascher, T. (2019). Swiss principals' emotions, basic needs satisfaction and readiness for change during curriculum reform. Journal of Educational Change, 20, 165-192. https ://doi.org/10.1007/s10833-019-09339-1.

James, M., \& McCormick, R. (2009). Teachers learning how to learn. Teaching and Teacher Education, 25(7), 973-982. https://doi.org/10.1016/j.tate.2009.02.023.

Jones, P., Forlin, C., \& Gillies, A. (2013). The contribution of facilitated leadership to systems development for greater inclusive practices. International Journal of Whole Schooling, 9(1), 60-74.

Kawai, R., Serriere, S., \& Mitra, D. (2014). Contested spaces of a "failing" elementary school. Theory and Research in Social Education, 42(4), 486-515. https://doi.org/10.1080/00933104.2014.96687 6.

Ketelaar, E., Beijaard, D., Boshuizen, H. P. A., \& Den Brok, P. J. (2012). Teachers' positioning towards an educational innovation in the light of ownership, sense-making and agency. Teaching and Teacher Education, 28(2), 273-282. https://doi.org/10.1016/j.tate.2011.10.004.

Klassen, R. M. (2010). Teacher stress: The mediating role of collective efficacy beliefs. The Journal of Educational Research, 103(5), 342-350. https://doi.org/10.1080/00220670903383069.

Klassen, R. M., \& Durksen, T. L. (2014). Weekly self-efficacy and work stress during the teaching practicum: A mixed methods study. Learning and Instruction, 33, 158-169. https://doi.org/10.1016/j. learninstruc.2014.05.003.

Kondakci, Y., Beycioglu, K., Sincar, M., \& Ugurlu, C. T. (2017). Readiness of teachers for change in schools. International Journal of Leadership in Education, 20(2), 176-197. https://doi. org/10.1080/13603124.2015.1023361.

Könings, K. D., Brand-Gruwel, S., \& van Merriënboer, J. J. G. (2007). Teachers' perspectives on innovations: Implications for educational design. Teaching and Teacher Education, 23(6), 985-997. https ://doi.org/10.1016/j.tate.2006.06.004.

Kyriacou, C. (2001). Teacher stress: Directions for future research. Educational Review, 53(1), 27-35. https://doi.org/10.1080/00131910120033628.

Lainas, A. (2010). Local directors of school education in Greece: Their role and main sources of job stress. Educational Management Administration \& Leadership, 38(4), 454-471. https://doi. org/10.1177/1741143210368145.

Lasky, S. (2005). A sociocultural approach to understanding teacher identity, agency and professional vulnerability in a context of secondary school reform. Teaching and Teacher Education, 21(8), 899-916. https://doi.org/10.1016/j.tate.2005.06.003.

Leana, C. R. (2011). The missing LINK in school reform. Stanford Social Innovation Review, 9, $30-35$.

Leithwood, K., Jantzi, D., \& Mascall, B. (2002). A framework for research on large-scale reform. Journal of Educational Change, 3(1), 7-33. https://doi.org/10.1023/A:1016527421742.

López-Yáñez, J., \& Sánchez-Moreno, M. (2013). Levers for sustainable improvement of Spanish schools in challenging contexts. Journal of Educational Change, 14(2), 203-232. https://doi. org/10.1007/s10833-012-9198-x.

März, V., \& Kelchtermans, G. (2013). Sense-making and structure in teachers' reception of educational reform. A case study on statistics in the mathematics curriculum. Teaching and Teacher Education, 29, 13-24. https://doi.org/10.1016/j.tate.2012.08.004.

McCormick, J., Ayres, P. L., \& Beechey, B. (2006). Teaching self-efficacy, stress and coping in a major curriculum reform: Applying theory to context. Journal of Educational Administration, 44(1), 53-70. https://doi.org/10.1108/09578230610642656. 
Mendenhall, A. N., Iachini, A., \& Anderson-Butcher, D. (2013). Exploring stakeholder perceptions of facilitators and barriers to implementation of an expanded school improvement model. Children \& Schools, 35(4), 225-234. https://doi.org/10.1093/cs/cdt011.

Miles, J., \& Shevlin, M. (2007). A time and a place for incremental fit indices. Personality and Individual Differences, 42(5), 869-874. https://doi.org/10.1016/j.paid.2006.09.022.

Montgomery, C., \& Rupp, A. A. (2005). A meta-analysis for exploring the diverse causes and effects of stress in teachers. Canadian Journal of Education, 28(3), 458-486. https://doi. org/10.2307/4126479.

Muthén, L. K., \& Muthén, B. O. (2012). Mplus: Statistical analysis with latent variables-User's guide (7th ed.). Los Angeles: Muthén \& Muthén.

Newmann, F. M., Smith, B., Allensworth, E., \& Bryk, A. S. (2001). Instructional program coherence: What it is and why it should guide school improvement policy. Educational Evaluation and Policy Analysis, 23(4), 297-321. https://doi.org/10.3102/01623737023004297.

Ng, S. W. (2009). Why did principals and teachers respond differently to curriculum reform? Teacher Development, 13(3), 187-203. https://doi.org/10.1080/13664530903335558.

Nunnally, J. C., \& Bernstein, I. H. (1994). Psychometric theory (3rd ed.). New York: McGraw-Hill.

Petko, D., Egger, N., Cantieni, A., \& Wespi, B. (2015). Digital media adoption in schools: Bottomup, top-down, complementary or optional? Computers \& Education, 84, 49-61. https://doi. org/10.1016/j.compedu.2014.12.019.

Pietarinen, J., Pyhältö, K., Soini, T., \& Salmela-Aro, K. (2013). Reducing teacher burnout: A sociocontextual approach. Teaching and Teacher Education, 35, 62-72. https://doi.org/10.1016/j. tate.2013.05.003.

Pietarinen, J., Pyhältö, K., \& Soini, T. (2017). Large-scale curriculum reform in Finland - exploring the interrelation between implementation strategy, the function of the reform, and curriculum coherence. The Curriculum Journal, 28(1), 22-40. https://doi.org/10.1080/09585176.2016.1179205.

Poirel, E., Lapointe, P., \& Yvon, F. (2012). Coping with administrative constraints by Quebec school principals. Canadian Journal of School Psychology, 27(4), 302-318. https://doi. org/10.1177/0829573512461131.

Priestley, M., Biesta, G., Philippou, S., \& Robinson, S. (2015). The teacher and the curriculum: Exploring teacher agency. In D. Wyse, L. Hayward, \& J. Pandya (Eds.), The SAGE handbook of curriculum, pedagogy and assessment (pp. 187-201). London: SAGE Publications Ltd.

Pyhältö, K., Soini, T., \& Pietarinen, J. (2011a). A systemic perspective on school reform. Journal of Educational Administration, 49(1), 46-61. https://doi.org/10.1108/09578231111102054.

Pyhältö, K., Pietarinen, J., \& Salmela-Aro, K. (2011b). Teacher-working-environment fit as a framework for burnout experienced by Finnish teachers. Teaching and Teacher Education, 27(7), 1101-1110. https://doi.org/10.1016/j.tate.2011.05.006.

Pyhältö, K., Pietarinen, J., \& Soini, T. (2012). Do comprehensive school teachers perceive themselves as active professional agents in school reforms? Journal of Educational Change, 13(1), 95-116. https ://doi.org/10.1007/s10833-011-9171-0.

Pyhältö, K., Pietarinen, J., \& Soini, T. (2014). Comprehensive school teachers' professional agency in large-scale educational change. Journal of Educational Change, 15(3), 303-325. https://doi. org/10.1007/s10833-013-9215-8.

Pyhältö, K., Pietarinen, J., \& Soini, T. (2015). Teachers' professional agency and learning - from adaptation to active modification in the teacher community. Teachers and Teaching: Theory and Practice, 21(7), 811-830. https://doi.org/10.1080/13540602.2014.995483.

Ramberg, M. R. (2014). What makes reform work? School-based conditions as predictors of teachers' changing practice after a national curriculum reform. International Education Studies, 7(6), 46-65. https://doi.org/10.5539/ies.v7n6p46.

Rauste-von Wright, M. (2001). The function of curriculum and the concept of learning. In E. Kimonen (Ed.), Curriculum approaches. Readings and activities for educational studies (pp. 21-34). Jyväskylä: Institute for Educational Research, University of Jyväskylä.

Resnick, L. B., \& Hall, M. W. (1998). Learning organizations for sustainable education reform. Daedalus, 127(4), 89-118.

Sahlberg, P. (2015). Finnish lessons 2.0: What can the world learn from educational change in Finland? (2nd ed.). New York: Teachers College Press.

Saunders, R. (2013). The role of teacher emotions in change: Experiences, patterns and implications for professional development. Journal of Educational Change, 14(3), 303-333. https://doi. org/10.1007/s10833-012-9195-0. 
Schmidt, M., \& Datnow, A. (2005). Teachers' sense-making about comprehensive school reform: The influence of emotions. Teaching and Teacher Education, 21(8), 949-965. https://doi.org/10.1016/j. tate.2005.06.006.

Schwarzer, R. \& Taubert, S. (2002). Tenacious goal pursuits and striving toward personal growth: Proactive coping. In E. Frydenberg (Ed.), Beyond coping: Meeting goals, visions, and challenges (pp. 19-35). New York: Oxford University Press. http://citeseerx.ist.psu.edu/viewdoc/download?doi=1 0.1.1.533.5201\&rep=rep1\&type=pdf. Retrieved April 27, 2017.

Soini, T., Pietarinen, J., \& Pyhältö, K. (2018). Shared sense-making strategies in curriculum reform: District-level perspective. Improving Schools, 21(2), 111-126. https://doi.org/10.1177/1365480217 744290.

Soini, T., Pyhältö, K., \& Pietarinen, J. (2010). Pedagogical well-being: Reflecting learning and wellbeing in teachers' work. Teachers and Teaching: Theory and Practice, 16(6), 735-751. https://doi. org/10.1080/13540602.2010.517690.

Sondergeld, T. A., \& Koskey, K. L. (2011). Evaluating the impact of an urban comprehensive school reform: An illustration of the need for mixed methods. Studies in Educational Evaluation, 37(2), 94-107. https://doi.org/10.1016/j.stueduc.2011.08.001.

Spillane, J. P., Reiser, B. J., \& Reimer, T. (2002). Policy implementation and cognition: Reframing and refocusing implementation research. Review of Educational Research, 72(3), 387-431. https://doi. org/10.3102/00346543072003387.

Stoll, L., Bolam, R., McMahon, A., Wallace, M., \& Thomas, S. (2006). Professional learning communities: A review of literature. Journal of Educational Change, 7(4), 221-258. https://doi.org/10.1007/ s10833-006-0001-8.

Stosich, E. L. (2016). Joint inquiry: Teachers' collective learning about the common core in highpoverty urban schools. American Educational Research Journal, 53, 1698-1731. https://doi. org/10.3102/0002831216675403.

Straud, C., McNaughton-Cassill, M., \& Fuhrman, R. (2015). The role of the five factor model of personality with proactive coping and preventative coping among college students. Personality and Individual Differences, 83, 60-64. https://doi.org/10.1016/j.paid.2015.03.055.

Sullanmaa, J., Pyhältö, K., Pietarinen, J., \& Soini, T. (2019). Curriculum coherence as perceived by district-level stakeholders in large-scale national curriculum reform in Finland. The Curriculum Journal, 30(3), 244-263. https://doi.org/10.1080/09585176.2019.1607512.

The Finnish National Board of Education. (2014). National core curriculum. http://www.oph.fi/downl oad/139848_pops_web.pdf. Retrieved January 31, 2017.

Thoonen, E. E. J., Sleegers, P. J. C., Oort, F. J., \& Peetsma, T. T. D. (2012). Building school-wide capacity for improvement: The role of leadership, school organizational conditions, and teacher factors. School Effectiveness and School Improvement, 23(4), 441-460. https://doi.org/10.1080/09243 453.2012.678867.

Tikkanen, L., Pyhältö, K., Soini, T., \& Pietarinen, J. (2017). Primary determinants of a large-scale curriculum reform - National board administrators' perspectives. Journal of Educational Administration, 55(6), 702-716. https://doi.org/10.1108/JEA-10-2016-0119.

Toh, Y. (2016). Leading sustainable pedagogical reform with technology for student-centred learning: A complexity perspective. Journal of Educational Change, 17(2), 145-169. https://doi.org/10.1007/ s10833-016-9273-9.

Troudi, S., \& Alwan, F. (2010). Teachers' feelings during curriculum change in the United Arab Emirates: Opening pandora's box. Teacher Development, 14(1), 107-121. https://doi.org/10.1080/13664 531003696659.

Underwood, P. W. (2000). Chapter 14: Social support-The promise and the reality. In V. H. Rice (Ed.), Handbook of stress, coping and health: Implications for nursing research, theory and practice (pp. 355-380). Thousand Oaks: Sage Publications.

Valli, L., \& Buese, D. (2007). The changing roles of teachers in an era of high-stakes accountability. American Educational Research Journal, 44(3), 519-558. https://doi.org/10.3102/0002831207 306859.

Van den Akker, J. (2003). Curriculum perspectives: An introduction. In J. J. H. van den Akker, W. A. J. M. Kuiper, \& U. Hameyer (Eds.), Curriculum landscapes and trends (pp. 1-10). Dordrecht: Kluwer Academic Publishers.

Van Droogenbroeck, F., Spruyt, B., \& Vanroelen, C. (2014). Burnout among senior teachers: Investigating the role of workload and interpersonal relationships at work. Teaching and Teacher Education, 43, 99-109. https://doi.org/10.1016/j.tate.2014.07.005. 
Van Veelen, R., Sleegers, P. J. C., \& Endedijk, M. D. (2017). Professional learning among school leaders in secondary education: The impact of personal and work context factors. Educational Administration Quarterly, 53(3), 365-408. https://doi.org/10.1177/0013161X16689126.

Van Veen, K., \& Sleegers, P. (2006). How does it feel? Teachers' emotions in a context of change. Journal of Curriculum Studies, 38(1), 85-111. https://doi.org/10.1080/00220270500109304.

Van Veen, K., Sleegers, P., \& van de Ven, P. (2005). One teacher's identity, emotions, and commitment to change: A case study into the cognitive-affective processes of a secondary school teacher in the context of reforms. Teaching and Teacher Education, 21(8), 917-934. https://doi.org/10.1016/j. tate.2005.06.004.

Verešová, M., \& Malá, D. (2012). Stress, proactive coping and self-efficacy of teachers. Procedia: Social and Behavioral Sciences, 55, 294-300. https://doi.org/10.1016/j.sbspro.2012.09.506.

Vitikka, E., Krokfors, L., \& Hurmerinta, E. (2012). The Finnish national core curriculum: Structure and development. In H. Niemi, A. Toom, \& A. Kallioniemi (Eds.), Miracle of education (pp. 83-96). Rotterdam: Sense.

Weick, K. E., Sutcliffe, K. M., \& Obstfeld, D. (2005). Organizing and the process of sensemaking. Organization Science, 16(4), 409-421. https://doi.org/10.1287/orsc.1050.0133.

Westman, M., \& Etzion, D. (1999). The crossover of strain from school principals to teachers and vice versa. Journal of Occupational Health Psychology, 4(3), 269-278. https://doi. org/10.1037/1076-8998.4.3.269.

Wilcox, K. C., \& Lawson, H. A. (2018). Teachers' agency, efficacy, engagement, and emotional resilience during policy innovation implementation. Journal of Educational Change, 19, 181-204. https:// doi.org/10.1007/s10833-017-9313-0.

Woolfolk Hoy, A., Davis, H., \& Pape, S. J. (2006). Teacher knowledge and beliefs. In P. A. Alexander \& P. H. Winne (Eds.), Handbook of educational psychology (2nd ed., pp. 715-737). Mahwah: Lawrence Erlbaum.

Yu, X., Wang, P., Zhai, X., Dai, H., \& Yang, Q. (2015). The effect of work stress on job burnout among teachers: The mediating role of self-efficacy. Social Indicators Research, 122(3), 701-708. https:// doi.org/10.1007/s11205-014-0716-5.

Yuen, T. W. W., Cheung, A. C. K., \& Wong, P. M. (2012). A study of the impact of the first phase of the curriculum reform on student learning in Hong Kong. The International Journal of Educational Management, 26(7), 710-728. https://doi.org/10.1108/09513541211263782.

Publisher's Note Springer Nature remains neutral with regard to jurisdictional claims in published maps and institutional affiliations.

\section{Affiliations}

\section{Lotta Tikkanen $^{1} \mathbb{D} \cdot$ Kirsi Pyhältö $^{1,2} \cdot$ Janne Pietarinen $^{3} \cdot$ Tiina Soini $^{4}$}

Kirsi Pyhältö

kirsi.pyhalto@helsinki.fi

Janne Pietarinen

janne.pietarinen@uef.fi

Tiina Soini

tiina.soini-ikonen@tuni.fi

1 Faculty of Educational Sciences, University of Helsinki, Siltavuorenpenger 1B, P.O. Box 9, 00014 Helsinki, Finland

2 Faculty of Education, University of Oulu, Oulu, Finland

3 School of Applied Educational Science and Teacher Education, University of Eastern Finland, Yliopistokatu 2, P.O. Box 111, 80101 Joensuu, Finland

4 Faculty of Education and Culture, Tampere University, Virta (Åkerlundinkatu 5), 33014 Tampere, Finland 